\title{
Shorter snow cover duration since 1970 in the Swiss Alps due to earlier snowmelt more than to later snow onset
}

\author{
Geoffrey Klein $^{1,2}$ - Yann Vitasse ${ }^{1,2,3} \cdot$ Christian Rixen $^{3}$ • \\ Christoph Marty $^{3} \cdot$ Martine Rebetez $^{1,2}$
}

Received: 12 May 2016/Accepted: 4 September 2016/Published online: 21 September 2016

(C) Springer Science+Business Media Dordrecht 2016

\begin{abstract}
Global warming has strong impacts on snow cover, which in turn affects ecosystems, hydrological regimes and winter tourism. Only a few long-term snow series are available worldwide, especially at high elevation. Here, we analyzed several snowpack characteristics over the period 1970-2015 at eleven meteorological stations, spanning elevations from 1139 to $2540 \mathrm{~m}$ asl in the Swiss Alps. Snow cover duration has significantly shortened at all sites, on average by 8.9 days decade ${ }^{-1}$. This shortening was largely driven by earlier snowmelt (on average 5.8 days decade ${ }^{-1}$ ) and partly by later snow onset but the latter was significant in only $\sim 30 \%$ of the stations. On average, the snow season now starts 12 days later and ends 26 days earlier than in 1970. Overall, the annual maximum snow depth has declined from 3.9 to $10.6 \%$ decade $^{-1}$ and was reached $7.8 \pm 0.4$ to $12.0 \pm 0.4$ days decade ${ }^{-1}$ earlier, though these trends hide a high inter-annual and decadal variability. The number of days with snow on the ground has also significantly decreased at all elevations, in all regions and for all thresholds from 1 to $100 \mathrm{~cm}$. Overall, our results demonstrate a marked decline in all snowpack parameters, irrespective of elevation and region, and whether for drier or wetter locations, with a pronounced shift of the snowmelt in spring, in connection with reinforced warming during this season.
\end{abstract}

Geoffrey Klein

geoffrey.klein@unine.ch

1 Institute of Geography, University of Neuchatel, Espace Louis Agassiz 1, CH-2000 Neuchatel, Switzerland

2 WSL Swiss Federal Institute for Forest, Snow and Landscape Research, Neuchatel, Switzerland

3 WSL Institute for Snow and Avalanche Research SLF, Davos, Switzerland 


\section{Introduction}

Increasing temperatures during the 20th and early 21 st centuries have caused a global reduction of the cryosphere (IPCC 2013). The snow cover has declined worldwide both in lowland areas (IPCC 2013) and in mountainous regions (Park et al. 2012; Pederson et al. 2013; Xu et al. 2015), including the European Alps (Durand et al. 2009; Marty 2008; Valt and Cianfarra 2010). The snow cover is projected to further decrease in the Northern Hemisphere from -7 to $-25 \%$ by the end of the century, depending on climate scenarios (IPCC 2013), and similar changes are also expected in the European Alps (Schmucki et al. 2015).

The seasonal year-to year variability of the snow cover is mainly driven by large-scale weather pattern anomalies (Scherrer and Appenzeller 2006; Seager et al. 2010), but also by regional and altitudinal patterns (Laternser and Schneebeli 2003). Long-term measurement series of snow cover in the Swiss Alps were shown to follow the same significant decreasing trend, both in the mean snow depth (or height of snowpack, HS, according to (Fierz et al. 2009)) and in the duration of the snow season at elevations below $1600 \mathrm{~m}$ asl, with only a slight decrease documented above this elevation (Laternser and Schneebeli 2003).

Since the 1980s, a rapid temperature increase has caused numerous abrupt environmental changes worldwide (Reid et al. 2015). This rapid warming was also observed in the European Alps (Marty 2008) and has been particularly pronounced in spring (Acquaotta et al. 2015; Rebetez and Reinhard 2008). Warmer temperatures were shown to be the major cause of the shorter snow cover duration in the European Alps (Hantel and Hirtl-Wielke 2007; Scherrer et al. 2004; Serquet et al. 2011). In fact, the reduction of the snow cover duration can be caused either by accelerated snowmelt due to warmer temperatures in spring (Rixen et al. 2012; Wielke et al. 2004) and/or reduced snowfalls during the winter season (Marty and Blanchet 2012; Scherrer et al. 2013). The latter could be the consequence of a decrease in the snow/rain ratio, as observed in the Swiss Alps in winter (Serquet et al. 2011), late autumn (Serquet et al. 2013) and spring (Marty and Meister 2012; Serquet et al. 2013).

In snow-dominated regions, the snow cover has serious implications for hydrological regimes and ecosystems (Callaghan et al. 2011), as well as for winter tourism (Damm et al. 2016). An upward shift of the snow line was already observed over the last decades in different mountain regions, as for instance in Tanzania at Mt. Kilimanjaro (Park et al. 2012) or in central Chile (Casassa et al. 2003). Similarly, the upper limit of the treeline, mainly driven by warmer temperatures during the growing season (Körner 2012), has increased at half of the 166 study sites worldwide (Harsch et al. 2009), and a significant upward shift of the vegetation was observed in mountainous areas in Europe (Lenoir et al. 2008). As vegetation and snow are tightly linked in cold biomes, especially the beginning of growth and snowmelt (Vitasse et al. 2016), it is crucial to assess to what extent the duration and amount of snow cover is currently affected by ongoing climate change at higher elevations to better anticipate future consequences for mountain ecosystems.

The majority of the studies that examine changes in snow conditions in relation to global warming focus on the period of the meteorological winter (DJF) and often ignore changes occurring in autumn and spring. In this study, we examine long-term series of HS measurements in the Swiss Alps over the whole year, using data from weather stations with manual snow observations at elevations ranging between 1139 and $2540 \mathrm{~m}$ asl. We studied how the snowpack has changed in the Swiss Alps over the period 1970-2015, with the aims (i) to test whether changes could be detected in different snow parameters related to HS and to snow 
cover duration and if snow cover duration has declined, (ii) to determine whether this reduction is mainly the cause of earlier snowmelt or later snow onset or both.

\section{Data and methods}

\subsection{Selection of the study sites}

We used daily manual HS data provided by the Swiss Federal Office of Meteorology and Climatology (MeteoSwiss). We selected stations from the Swiss Alps with a continuous snow cover for at least $90 \%$ of the years during the longest available common period, being 19702015. All data series were manually controlled and tested for outliers and missing data. Metadata stored by MeteoSwiss were checked for all events reported which might have impacted the data quality. The measurement method remained unchanged during the period taken into account. A continuous snow cover was defined as at least 40 consecutive days ( 6 weeks) with a minimum of $1 \mathrm{~cm}$ of HS on the ground. Defining the threshold at either minimum 30 or 50 consecutive days did not change the number of qualifying stations.

We analyzed nine snowpack parameters (see below, section 2.2), for all stations and years providing at least $90 \%$ of available data. We considered stations having at least $90 \%$ of annual resulting data for each parameter over the study period. This threshold was verified and found to be robust for all stations using a bootstrap method. In detail, we tested trend significances of 1000 samples for which 5,10,15 and $20 \%$ of the annual resulting data was randomly removed.

Most of the selected stations were slightly relocated during the study period (maximum $90 \mathrm{~m}$ of elevation and $2.2 \mathrm{~km}$ of distance on the same slope), except one station (Säntis) which experienced a significant relocation in 1978 (Marty and Meister 2012). Data for all snow parameters were checked for consistency at the dates of relocations for each station, and no changes in trends were found, except for one station (Säntis) which was therefore discarded.

Following this filtering procedure, eleven stations were finally selected for our study. Their elevations range from 1139 to $2540 \mathrm{~m}$ asl, with a mean snow cover duration from 108 to 260 days and a mean maximum HS from 65 to $353 \mathrm{~cm}$ over the study period (Table 1).

\subsection{Snow data}

The annual snow parameters were considered from 1 September until 31 August of the following year. This period was chosen based on the earliest snow onset date (6 September 1984), and latest snowmelt date (16 August 1980) of all our stations, which were both found at the highest site (Weissfluhjoch). For all snow parameters, years are designated by the calendar year when the snow season ends. Before extracting all snow parameters, data gaps equal to one day were filled by linear interpolation for a better homogeneity in the raw data.

For each snow year and station, we looked at nine parameters: the maximum HS, the times of snow onset, snowmelt and maximum HS, the snow cover duration and the number of days with $\mathrm{HS} \geq 1,20,50$ and $100 \mathrm{~cm}$ (days with snowpack, called hereafter DSP). The highest threshold was not meaningful for three stations (Scuol, Sta. Maria Val Müstair, and Grächen), due to their dryer climate and on average lower maximum HS (65, 70 and $74 \mathrm{~cm}$ respectively, see Table 1). The snow onset date was defined as the first day of the first continuous snow cover period and the snowmelt date as the first snow-free day after the last continuous snow 
Table 1 Selected stations for the long-term trend analysis of the snow parameters. Coordinates, elevation, mean snow cover duration and mean maximum HS over the study period (1970-2015) are reported. Coordinates and elevation correspond to the snow measurement location (often slightly apart from the other meteorological measurements)

\begin{tabular}{|c|c|c|c|c|c|}
\hline Station & Code & Coordinates & $\begin{array}{l}\text { Elevation } \\
{[\mathrm{m} \text { asl }]}\end{array}$ & $\begin{array}{l}\text { Mean snow } \\
\text { cover duration } \\
\text { [days] }\end{array}$ & $\begin{array}{l}\text { Mean maximum } \\
\mathrm{HS}[\mathrm{cm}]\end{array}$ \\
\hline Airolo & AIR & $46^{\circ} 31^{\prime} 34^{\prime \prime} \mathrm{N} / 08^{\circ} 35^{\prime} 51^{\prime \prime} \mathrm{E}$ & 1139 & 111 & 111 \\
\hline Scuol & $\mathrm{SCU}$ & $46^{\circ} 47^{\prime} 36^{\prime \prime} \mathrm{N} / 10^{\circ} 16^{\prime} 59^{\prime \prime} \mathrm{E}$ & 1298 & 108 & 65 \\
\hline Sta. Maria Val Müstair & SMM & $46^{\circ} 35^{\prime} 55^{\prime \prime} \mathrm{N} / 10^{\circ} 25^{\prime} 34^{\prime \prime} \mathrm{E}$ & 1418 & 124 & 70 \\
\hline Andermatt & ANT & $46^{\circ} 38^{\prime} 00^{\prime \prime} \mathrm{N} / 08^{\circ} 35^{\prime} 40^{\prime \prime} \mathrm{E}$ & 1442 & 158 & 150 \\
\hline Bosco-Gurin & BOS & $46^{\circ} 19^{\prime} 00^{\prime \prime} \mathrm{N} / 08^{\circ} 29^{\prime} 19^{\prime \prime} \mathrm{E}$ & 1486 & 148 & 165 \\
\hline Grächen & GRC & $46^{\circ} 12^{\prime} 09^{\prime \prime} \mathrm{N} / 07^{\circ} 50^{\prime} 28^{\prime \prime} \mathrm{E}$ & 1550 & 120 & 74 \\
\hline Davos & DAV & $46^{\circ} 48^{\prime} 45^{\prime \prime} \mathrm{N} / 09^{\circ} 50^{\prime} 50^{\prime \prime} \mathrm{E}$ & 1560 & 156 & 110 \\
\hline Arosa & $\mathrm{ARO}$ & $46^{\circ} 47^{\prime} 31^{\prime \prime} \mathrm{N} / 09^{\circ} 40^{\prime} 59^{\prime \prime} \mathrm{E}$ & 1750 & 176 & 138 \\
\hline Segl-Maria & SIA & $46^{\circ} 26^{\prime} 21^{\prime \prime} \mathrm{N} / 09^{\circ} 45^{\prime} 56^{\prime \prime} \mathrm{E}$ & 1798 & 161 & 124 \\
\hline Grimsel Hospiz & GRH & $46^{\circ} 34^{\prime} 17^{\prime \prime} \mathrm{N} / 08^{\circ} 19^{\prime} 58^{\prime \prime} \mathrm{E}$ & 1970 & 220 & 353 \\
\hline Weissfluhjoch & WFJ & $46^{\circ} 49^{\prime} 47^{\prime \prime} \mathrm{N} / 09^{\circ} 48^{\prime} 33^{\prime \prime} \mathrm{E}$ & 2540 & 260 & 250 \\
\hline
\end{tabular}

cover period. The snow cover duration corresponds to the number of days between snow onset date and snowmelt date. In case of multiple identical values of maximum HS (78 occurrences, i.e. $15 \%$ of the station-years), we identified the latest occurrence as the date with maximum HS. Using the earliest occurrence showed no significant changes in the trend results.

Among the 506 station-years considered, only three had a continuous snow cover shorter than 40 consecutive days (Airolo 1989 and 1993, Scuol 2002). To avoid excluding these extreme cases due to a lack of snow, we computed the snow onset and snowmelt dates according to their longest continuous snow cover for these three occurrences (34, 36 and 15 days respectively).

In addition, two distinct continuous snow covered periods of more than 40 days during the same season were found for 5 station-years. For these specific cases, the snow cover duration therefore includes snow free days (4, 3, 40 and 2 days in 1990, respectively at Andermatt, Arosa, Bosco-Gurin and Sta. Maria Val Müstair, as well as 7 days in 2013 at Airolo).

\subsection{Statistics}

Because none of the analyzed snow parameters were following a normal distribution (verified using Shapiro tests), temporal trends were therefore calculated on the original annual values for each parameter and each station by applying the non-parametric Theil-Sen estimator slope, combined with a Mann-Kendall significance test over the common temporal period for all stations (1970-2015). No significant breaks in the slopes of the temporal trends were detected for any parameters and stations over the study period (tested by stepwise regression methods).

All analyses, tables and figures were performed using R 3.2 (Team RC 2015) and the following R-packages: EnvStats, kendall reshape2 and zoo. 


\section{Results}

\subsection{Time of snow onset, snowmelt and snow cover duration}

The time of snow onset was delayed at all eleven stations, and significantly at four of them by $3.1 \pm 0.2$ to $4.0 \pm 0.2$ days decade $^{-1}$ (Fig. 1a and Table 2). All stations showed a significantly earlier snowmelt, on average -5.8 days decade ${ }^{-1}$, ranging from $-3.6 \pm 0.2$ to $-7.5 \pm 0.2$ days decade $^{-1}$ (Fig. 1b and Table 2). As a result, the snow cover duration was significantly reduced at all stations by $6.2 \pm 0.2$ to $11.2 \pm 0.2$ days decade $^{-1}$ (Fig. 1c and Table 2), on average by 8.9 days decade ${ }^{-1}$, corresponding to a shortening of 2.6 to $7.5 \%$ decade $^{-1}$. No pattern or significant correlations were found neither between elevation and the changes in the timing of snow onset, snowmelt or snow cover duration (Pearson correlation $p$-values of $0.24,0.65$ and 0.63 , respectively), nor with geographic coordinates ( $p$-values $0.88,0.25$ and 0.11 , respectively, extracted from the multiple linear regression based on the geographic coordinates of the stations).
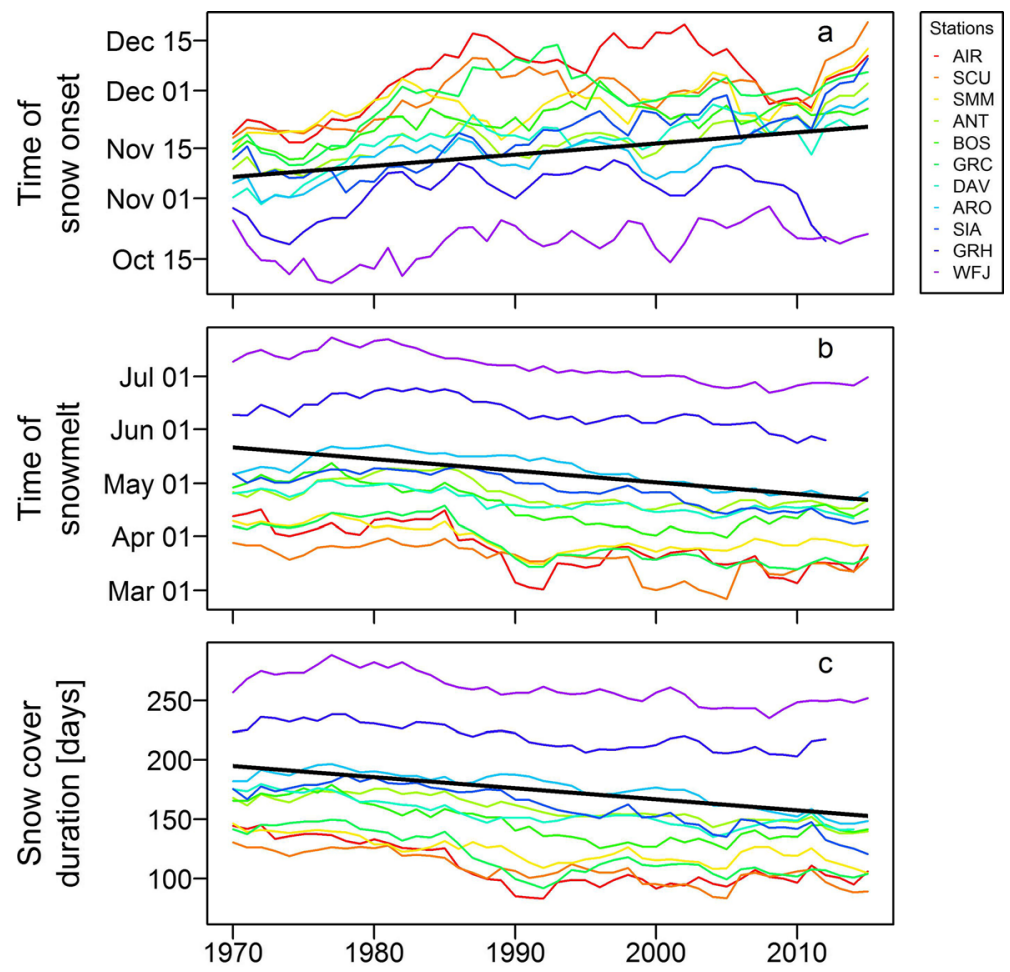

Year

Fig. 1 7-year simple moving average of the snow onset, snowmelt dates and snow cover duration of the eleven study stations over the period 1970-2015 (with half-windows on both edges). The bold line corresponds to the mean Sen slope of the eleven stations and was calculated by averaging all annual values across stations and then, computing the slope of the mean series. For station names, see Table 1, for individual slope values, see Table 2 


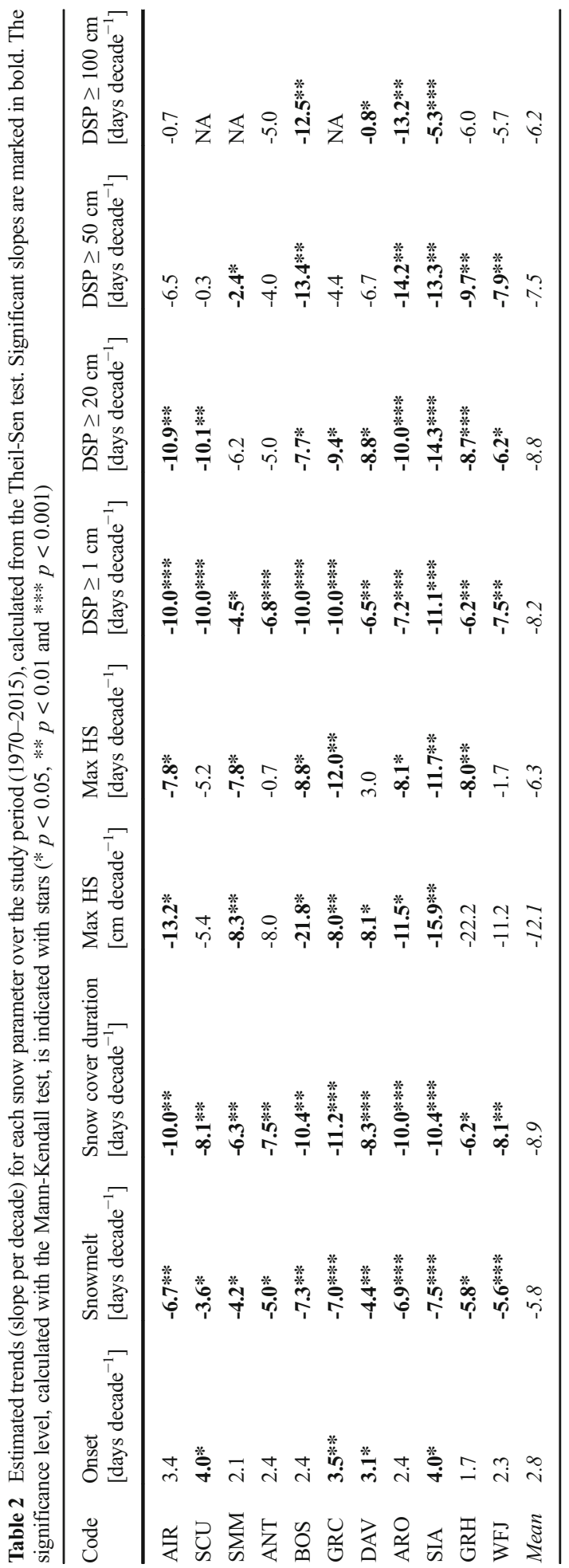




\subsection{Maximum HS (snow depth)}

The stations' average maximum HS ranged from 65 to $353 \mathrm{~cm}$, and decreased at all stations over the study period irrespective of elevation or geographical location. The decrease of the maximum HS was significant for seven stations with a rate from $8.0 \pm 0.6$ to $21.8 \pm 0.8 \mathrm{~cm} \mathrm{decade}^{-1}$ (Fig. 2a and Table 2), corresponding to a reduction from 3.9 to $10.6 \%$ decade $^{-1}$. The day of maximum HS occurred earlier at all sites except one (Davos), and significantly for seven stations with a rate from $7.8 \pm 0.4$ to $12.0 \pm 0.4$ days decade ${ }^{-1}$ (Fig. $2 \mathrm{~b}$ and Table 2). A highly significant correlation was found between maximum HS values and snowmelt date for all eleven stations (mean Pearson coefficient $r=0.68, p<0.0001$ ). Significant correlations were also found between maximum HS values and the snow onset date for five stations. No significant correlations were found between the times of maximum HS and snow onset, whereas significant correlations were found for six stations between the times of maximum HS and snowmelt.

\subsection{Frequency of DSP (frequency of days with snowpack)}

The frequency of DSP has decreased at all sites and for all thresholds $(1,20,50$ or $100 \mathrm{~cm})$. This decrease was significant at all stations for DSP $\geq 1 \mathrm{~cm}$ from $4.5 \pm 0.2$ to $11.1 \pm 0.2$ days decade $^{-1}$ (Fig. 3a and Table 2), at nine stations for DSP $\geq 20 \mathrm{~cm}$ from $6.2 \pm 0.3$ to $14.3 \pm 0.3$ days decade $^{-1}$ (Fig. $3 \mathrm{~b}$ and Table 2), at six stations for DSP $\geq 50 \mathrm{~cm}$ from $2.4 \pm 0.2$ to $14.2 \pm 0.4$ days decade $^{-1}$ (Fig. 3c and Table 2), and at four stations for DSP $\geq 100 \mathrm{~cm}$ (out of only eight stations for this last threshold as three were disregarded, see Data and methods section) from $0.8 \pm 0.2$ to $13.2 \pm 0.5$ days decade ${ }^{-1}$ (Fig. $3 \mathrm{~d}$ and Table 2). No significant correlations could be found between the reduction in the number of DSP and elevation ( $p$-values $0.54,0.67,0.24$ and 0.65 for

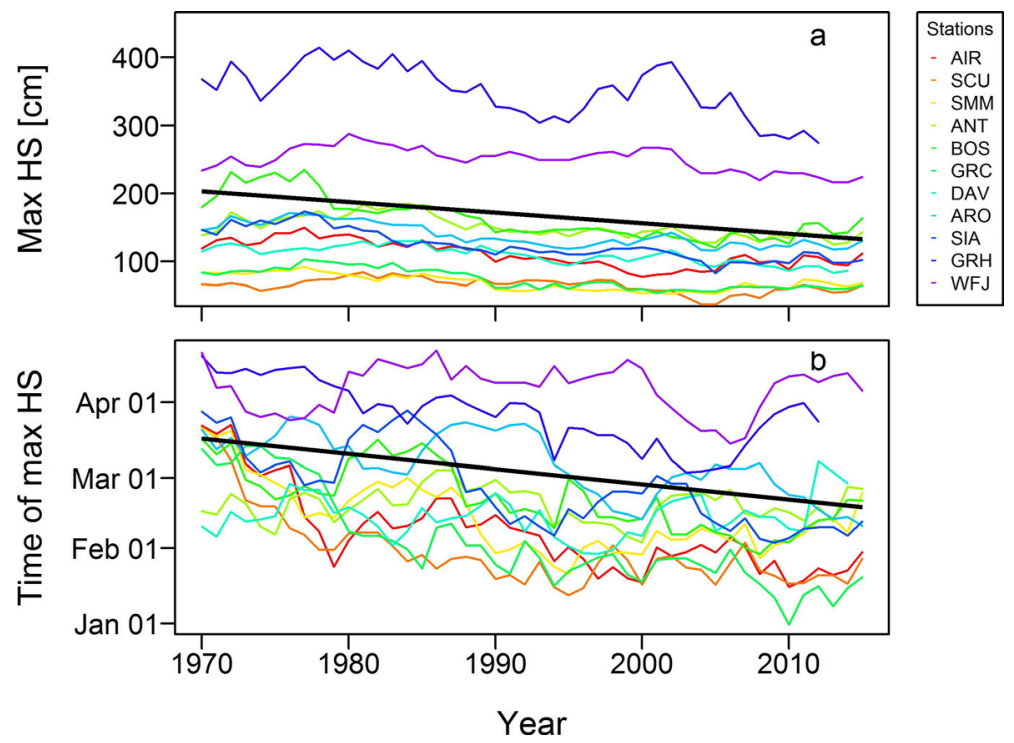

Fig. 2 7-year simple moving average of the maximum snow depth (HS) and its day of occurrence of the eleven study stations over the period 1970-2015 (with half-windows on both edges). The bold line corresponds to the mean Sen slope of the eleven stations and was calculated by averaging all annual values across stations and then, computing the slope of the mean series. For station names, see Table 1, for individual slope values, see Table 2 

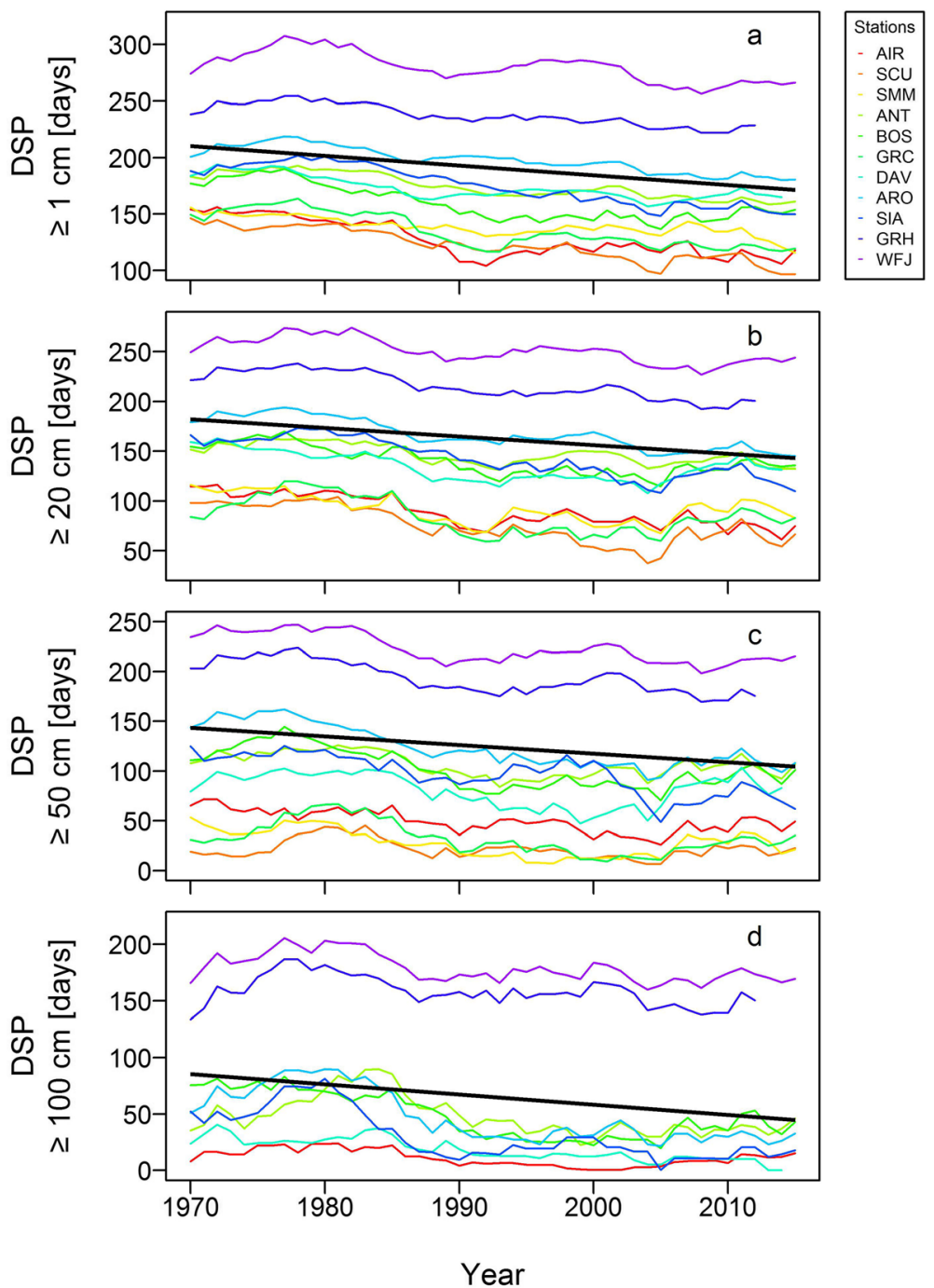

Fig. 3 7-year simple moving average of the days with snowpack (DSP) $\geq 1,20,50$ and $100 \mathrm{~cm}$ of the eleven study stations over the period 1970-2015 (with half-windows on both edges). The bold line corresponds to the mean Sen slope of the eleven stations and was calculated by averaging all annual values across stations and then, computing the slope of the mean series. For the DSP $\geq 100 \mathrm{~cm}$, the three driest stations (SCU, SMM and GRC) were omitted from the plot and the mean Sen slope calculation. Note that the y-axes are not all the same. For station names, see Table 1, for individual slope values, see Table 2

the thresholds $1,20,50$ and $100 \mathrm{~cm}$ respectively) or geographical location of the study sites (pvalues $0.33,0.65,0.70$ and 0.89 respectively).

\section{Discussion}

Our study shows that snow cover duration, as well as the maximum HS and the frequency of DSP have all clearly been declining in the Swiss Alps, irrespective of elevation (1139 to 
$2540 \mathrm{~m}$ asl) and location, and whether for stations with much or little snow. Complementary to numerous previous studies showing stronger declines in snow cover at elevations below $1600 \mathrm{~m}$ asl in the Alps (Durand et al. 2009; Laternser and Schneebeli 2003; Valt and Cianfarra 2010), during our study period 1970-2015, we found a significant snow cover decline at all elevations up to the highest elevation site (2540 m asl). Here, we analyzed the whole snow season including autumn and spring, whereas previous studies mainly considered the winter season, usually from December to February or March. The observed snowpack reduction is most likely related to the general increase in temperatures observed at all elevations in the Swiss Alps, especially during spring (Rebetez and Reinhard 2008). The impact of global warming on snowpack may have been additionally enhanced by an increasing trend in sunshine duration, observed at both low and high elevations in the European Alps from 1975 to 2000 (Auer et al. 2007) and in solar surface radiation in Switzerland from 1981 to 2010, particularly in spring (Sanchez-Lorenzo and Wild 2012). Our results do not show any regional or elevation-dependent trends but rather a clear decrease in all snow parameters at all stations.

The strong reduction in the snow cover duration was more the result of an earlier snowmelt than a later snow onset: the earlier snowmelt date was approximately twice as important as the delayed snow onset date, with a contribution accounting on average for $67 \%$ of the shortening of the snow season against $33 \%$ for snow onset. On average, among our stations, the snowmelt now takes place around 16 March at the lowest station (Airolo, at $1139 \mathrm{~m}$ asl on the southern side of the Swiss Alps) and around 25 June at the highest station (Weissfluhjoch, at $2540 \mathrm{~m}$ asl on the eastern part of the Swiss Alps), compared to 15 April and 20 July, respectively based on the linear trends. In autumn, the snow onset now takes place on average on 7 December at the lowest station and on 25 October at the highest station, whereas it was respectively on 22 November and 15 October in 1970.

The differences in observed changes in snow onset and snowmelt dates are coherent with the differences in seasonal temperature trends in the Swiss Alps, showing a stronger increase in spring $\left(+0.84{ }^{\circ} \mathrm{C}\right.$ decade $\left.^{-1}\right)$ than in autumn $\left(+0.21{ }^{\circ} \mathrm{C}\right.$ decade $\left.{ }^{-1}\right)$ since the 1970 s (Rebetez and Reinhard 2008; Serquet et al. 2013). The observed increasing trend in sunshine duration (Auer et al. 2007; Sanchez-Lorenzo and Wild 2012) may have had a particularly strong impact on snowmelt, as the sunrays are much higher in March-July compared to October-December, the time of snow onset. Thus, in addition to stronger temperature increasing trends in spring, the increasing sunshine duration may have contributed to the stronger shift observed in the time of snowmelt compared to the one detected in the time of snow onset. Particularly in spring, when the sun is higher than in late autumn, the changing albedo may also enhance the warming and melting process: the white snow cover disappeared earlier due to global warming, resulting into a decrease of the albedo. More energy was thus available on the ground, further increasing air temperature (Rebetez and Reinhard 2008), and accelerating the melting of snow. The resulting snow cover duration was consequently reduced both in the beginning and end of the season, lasting now only 98 days at the lowest station and 239 days at the highest, compared to 143 and 275 days respectively in 1970.

The observed decrease in maximum HS is consistent with previous studies, showing a decrease in maximum HS at all elevations in the Swiss Alps (Marty and Blanchet 2012). The significant correlations found between the snow onset date and the maximum HS values show that warmer temperatures and later snow onset in autumn contribute significantly to the reduction of the maximum snow amounts which can then be reached during the winter. Warmer temperatures in September to December have had an impact at the elevations where 
they were just below the zero-degree level (Serquet et al. 2013), resulting into rainfall instead of snowfall. These previous early snowfalls are now missing in the yearly maximum amount of HS. The high correlation between maximum HS and snowmelt date observed at all stations shows that these parameters are strongly interdependent. Although the time of snow onset is less variable than the time of snowmelt, there is no correlation between the times of maximum HS and snow onset. Our results clearly suggest that the time of maximum HS is mainly governed by warmer and possibly sunnier spring conditions when the snowpack starts melting. These relationships show how the temperature increase observed in spring has had a strong impact on the snow cover. Increasing temperatures in late autumn and spring have contributed to the snowfall/precipitation-day ratio decrease when the temperatures were not far below the zero-degree limit, which in turn has also contributed to the decrease in all snowpack parameters. The decline in the number of DSP was also found when using high thresholds of HS, which supports that the warmer past decades have also impacted the snowpack at locations having large amounts of snow precipitation, typically at higher elevations where colder temperatures and longer snow seasons occur. The highest thresholds used are relevant to confirm that a prominent decline in snowpack has also occurred in wetter regions with abundant precipitation. Former studies often did not look at these melting months and therefore concluded that there is little change in winter snowpack at higher elevations (Marty 2008; Scherrer et al. 2004).

Water resources in mountainous areas are tightly connected to the snow cover cycle. Numerous regions may be affected because our study area stands in a central position in Europe, at the source of three major drainage basins, the Rhine, Danube and Rhone rivers, with alpine basins having a strong influence on major distant downstream catchments crossing several countries. Earlier snowmelt and reduced snow accumulation during winter, as a consequence of global warming, can have a commensurable impact on plant and animals of alpine ecosystems, runoff regimes, soil moisture and water availability in the drainage basins (Barnett et al. 2005; Zierl and Bugmann 2005). For example, in the alpine belt, earlier snowmelts and warmer temperatures were found to cause earlier plant development (Ernakovich et al. 2014; Vitasse et al. 2016), which can put them at higher risk to be damaged by frost (Wipf et al. 2009). The combination of an earlier snowmelt and a shortening of the snow cover duration might also alter the spatial pattern of suitable habitats of some snowbed plant communities (Carbognani et al. 2014). Similarly, the reduction in the snow cover has already affected the reproduction of the alpine fauna, as for example the decreasing litter size of the Alpine marmot (Tafani et al. 2013).

The natural snow cover duration and HS is also crucial for winter tourism in mountain regions, because their reduction can drastically shift upward the snow-reliability limit for ski resorts and shorten the winter sports season (Pons et al. 2015). If snowpack continues to decline, artificial snow may also progressively become critical to produce for winter sports (Gajić-Čapka 2011; Steiger 2010), particularly at the beginning and at the end of the ski season (Rixen et al. 2011), due to temperatures more and more frequently above the freezing threshold at sensitive elevations and times of the year (Rixen et al. 2011; Serquet et al. 2011; Serquet et al. 2013). A relationship between HS and the overnight stays of tourists in ski resorts in Austria has been demonstrated for low and mid-elevation ski resorts, whereas the two parameters were independent for the high-elevation resorts (Falk 2010). Our results show that stations located at elevations higher than $1700 \mathrm{~m}$ asl still have more than 79 days (and 206 days at the highest station at $2540 \mathrm{~m}$ asl) with at least $50 \mathrm{~cm}$ of HS, irrespective of the timing of the ski season. Model results show that the reduction of the snow season and the stronger 
reduction of the snow cover at the end of the season will likely continue in the coming decades and that the snow reliability for winter tourism will become critical at elevations up to $1800 \mathrm{~m}$ asl and $2000 \mathrm{~m}$ asl by mid and end of the century, respectively (Steger et al. 2013). Specific results from climatic models have shown that the decline of snowpack could be moderate until 2050, but will likely accelerate during the second half of the century (Bavay et al. 2013). This could result into millions of overnight stays lost during the winter seasons (Damm et al. 2016). Our results show that this issue must be taken seriously into account for future prospects, even at higher elevations.

\section{Conclusions}

Our results show a clear reduction of the snowpack over the period 1970-2015 in the Swiss Alps, based on eleven stations from 1139 to $2540 \mathrm{~m}$ asl, irrespective of elevation or region. In particular, they show that snowpack has been decreasing at higher elevation to the same extent as it has declined at lower elevations. We found a clear shortening of the continuous snow cover duration, on average by 8.9 days decade ${ }^{-1}$, irrespective of the region or elevation. The reduction in snow cover duration is mostly the result of earlier snowmelt (on average by 5.8 days decade ${ }^{-1}$ ), rather than later snow onset, likely mostly due to a higher temperature increase in spring compared to autumn. On average, the snow season now starts 12 days later and ends 26 days earlier than in 1970. We also found a general decline in the value of the annual maximum HS, in connection with the later snow onset. The time of maximum HS also occurred earlier, and was highly connected to the snowmelt date and much less to the time of snow onset, illustrating the impact of the spring temperatures and of the earlier start of the melting period on the snow season. The number of DSP has decreased at all elevations, in all regions and irrespective of the HS threshold. Our results show particularly strong trends of snow decline in spring, which may progressively lead to increasing consequences on hydrological regimes and on summer water availability, whether for ecosystems or for society.

Acknowledgments This work was supported by the Swiss National Science Foundation (grant number 200021-152954). We are grateful to MeteoSwiss for providing the snow data, to Stephan Bader and Gergely Rigo for their help concerning the snow stations' metadata, to Christophe Randin for his help with data analysis and to William Doehler for his editorial improvements of the manuscript.

\section{References}

Acquaotta F, Fratianni S, Garzena D (2015) Temperature changes in the north-western Italian alps from 1961 to 2010. Theor Appl Climatol 122:619-634

Auer I, Böhm R, Jurkovic A, Lipa W, Orlik A, Potzmann R, Schöner W, Ungersböck M, Matulla C, Briffa K (2007) HISTALP - historical instrumental climatological surface time series of the greater alpine region. Int J Climatol 27:17-46

Barnett TP, Adam JC, Lettenmaier DP (2005) Potential impacts of a warming climate on water availability in snow-dominated regions. Nature 438:303-309

Bavay M, Grünewald T, Lehning M (2013) Response of snow cover and runoff to climate change in high Alpine catchments of Eastern Switzerland. Adv Water Resour 55:4-16 
Callaghan TV, Johansson M, Brown RD, Groisman PY, Labba N, Radionov V, Bradley RS, Blangy S, Bulygina ON, Christensen TR (2011) Multiple effects of changes in Arctic snow cover. Ambio 40:32-45

Carbognani M, Tomaselli M, Petraglia A (2014) Current vegetation changes in an alpine late snowbed community in the south-eastern alps (N-Italy. Alp Bot 124:105-113

Casassa G, Rivera A, Escobar F, Acuña C, Carrasco J, Quintana J (2003) Snow line rise in Central Chile in recent decades and its correlation with climate. in EGS-AGU-EUG Joint Assembly, p. 14395.

Damm A, Greuell W, Landgren O, Prettenthaler F (2016) Impacts of $+2{ }^{\circ} \mathrm{C}$ global warming on winter tourism demand in Europe. Climate Services.

Durand Y, Giraud G, Laternser M, Etchevers P, Mérindol L, Lesaffre B (2009) Reanalysis of 47 years of climate in the French Alps (1958-2005): Climatology and trends for snow cover. J Appl Meteorol Climatol 48: 2487-2512

Ernakovich JG, Hopping KA, Berdanier AB, Simpson RT, Kachergis EJ, Steltzer H, Wallenstein MD (2014) Predicted responses of arctic and alpine ecosystems to altered seasonality under climate change. Glob Chang Biol 20:3256-3269

Falk M (2010) A dynamic panel data analysis of snow depth and winter tourism. Tour Manag 31:912-924

Fierz C, Armstrong RL, Durand Y, Etchevers P, Greene E, McClung DM, Nishimura K, Satyawali PK, Sokratov SA (2009) The international classification for seasonal snow on the ground. UNESCO/IHP Paris.

Gajić-Čapka M (2011) Snow climate baseline conditions and trends in Croatia relevant to winter tourism. Theor Appl Climatol 105:181-191

Hantel M, Hirtl-Wielke LM (2007) Sensitivity of alpine snow cover to European temperature. Int J Climatol 27: 1265-1275

Harsch MA, Hulme PE, McGlone MS, Duncan RP (2009) Are treelines advancing? A global meta-analysis of treeline response to climate warming. Ecol Lett 12:1040-1049

IPCC (2013) Climate Change 2013: The Physical Science Basis. Contribution of Working Group I to the Fifth Assessment Report of the Intergovernmental Panel on Climate Change. Cambridge University Press, Cambridge, United Kingdom and New York, NY, USA

Körner C (2012) Alpine treelines: functional ecology of the global high elevation tree limits. Springer Science \& Business Media.

Laternser M, Schneebeli M (2003) Long-term snow climate trends of the Swiss Alps (1931-99). Int J Climatol 23:733-750

Lenoir J, Gégout J-C, Marquet P, De Ruffray P, Brisse H (2008) A significant upward shift in plant species optimum elevation during the twentieth century. Science 320:1768-1771

Marty C (2008) Regime shift of snow days in Switzerland. Geophys Res Lett 35

Marty C, Blanchet J (2012) Long-term changes in annual maximum snow depth and snowfall in Switzerland based on extreme value statistics. Clim Chang 111:705-721

Marty C, Meister R (2012) Long-term snow and weather observations at Weissfluhjoch and its relation to other high-altitude observatories in the alps. Theor Appl Climatol 110:573-583

Park S-H, Lee M-J, Jung H-S (2012) Analysis on the snow cover variations at Mt. Kilimanjaro using Landsat satellite images. Korean Journal of Remote Sensing 28.

Pederson GT, Betancourt JL, McCabe GJ (2013) Regional patterns and proximal causes of the recent snowpack decline in the Rocky Mountains, US. Geophys Res Lett 40:1811-1816

Pons M, López-Moreno JI, Rosas-Casals M, Jover È (2015) The vulnerability of Pyrenean ski resorts to climateinduced changes in the snowpack. Clim Chang 131:591-605

Rebetez M, Reinhard M (2008) Monthly air temperature trends in Switzerland 1901-2000 and 1975-2004. Theor Appl Climatol 91:27-34

Reid PC, Hari RE, Beaugrand G, Livingstone DM, Marty C, Straile D, Barichivich J, Goberville E, Adrian R, Aono Y (2015) Global impacts of the 1980s regime shift. Global change biology.

Rixen C, Teich M, Lardelli C, Gallati D, Pohl M, Pütz M, Bebi P (2011) Winter tourism and climate change in the alps: an assessment of resource consumption, snow reliability, and future snowmaking potential. Mt Res Dev 31:229-236

Rixen C, Dawes MA, Wipf S, Hagedorn F (2012) Evidence of enhanced freezing damage in treeline plants during six years of CO2 enrichment and soil warming. Oikos 121:1532-1543

Sanchez-Lorenzo A, Wild M (2012) Decadal variations in estimated surface solar radiation over Switzerland since the late nineteenth century. Atmos Chem Phys 12:8635-8644

Scherrer SC, Appenzeller C (2006) Swiss alpine snow pack variability: major patterns and links to local climate and large-scale flow. Clim Res 32

Scherrer SC, Appenzeller C, Laternser M (2004) Trends in Swiss alpine snow days: the role of local-and largescale climate variability. Geophys Res Lett 31

Scherrer SC, Wüthrich C, Croci-Maspoli M, Weingartner R, Appenzeller C (2013) Snow variability in the Swiss alps 1864-2009. Int J Climatol 33:3162-3173 
Schmucki E, Marty C, Fierz C, Weingartner R, Lehning M (2015) Impact of climate change in Switzerland on socioeconomic snow indices. Theor Appl Climatol:1-15

Seager R, Kushnir Y, Nakamura J, Ting M, Naik N (2010) Northern Hemisphere winter snow anomalies: ENSO, NAO and the winter of 2009/10. Geophysical research letters 37.

Serquet G, Marty C, Dulex JP, Rebetez M (2011) Seasonal trends and temperature dependence of the snowfall/ precipitation-day ratio in Switzerland. Geophys Res Lett 38

Serquet G, Marty C, Rebetez M (2013) Monthly trends and the corresponding altitudinal shift in the snowfall/ precipitation day ratio. Theor Appl Climatol 114:437-444

Steger C, Kotlarski S, Jonas T, Schär C (2013) Alpine snow cover in a changing climate: a regional climate model perspective. Clim Dyn 41:735-754

Steiger R (2010) The impact of climate change on ski season length and snowmaking requirements in Tyrol, Austria. Climate research (Open Access for articles 4 years old and older) 43:251.

Tafani M, Cohas A, Bonenfant C, Gaillard J-M, Allainé D (2013) Decreasing litter size of marmots over time: a life history response to climate change? Ecology 94:580-586

Team RC (2015) R: A Language and Environment for Statistical Computing (R Foundation for Statistical Computing, Vienna, 2012). URL: http:// www.R-project. org.

Valt M, Cianfarra P (2010) Recent snow cover variability in the Italian alps. Cold Reg Sci Technol 64:146-157

Vitasse Y, Rebetez M, Filippa G, Cremonese E, Klein G, Rixen C (2016) Hearing'alpine plants growing after snowmelt: ultrasonic snow sensors provide long-term series of alpine plant phenology. Int $\mathrm{J}$ Biometeorol:1-13

Wielke L-M, Haimberger L, Hantel M (2004) Snow cover duration in Switzerland compared to Austria. Meteorol Z 13:13-17

Wipf S, Stoeckli V, Bebi P (2009) Winter climate change in alpine tundra: plant responses to changes in snow depth and snowmelt timing. Clim Chang 94:105-121

Xu Y, Ramanathan V, Washington W (2015) Observed high-altitude warming and snow cover retreat over Tibet and the Himalayas enhanced by black carbon aerosols. Atmos Chem Phys Discuss 15:19079-19109

Zierl B, Bugmann H (2005) Global change impacts on hydrological processes in alpine catchments. Water Resour Res 41 